УДК 633.111:631.559

(C) 2012

Жемела Г. П., доктор сільськогосподарських наук, професор, Шакалій С. М., аспірант*

Полтавська державна аграрна академія

\title{
ВПЛИВ ПОПЕРЕДНИКІВ НА ВРОЖАЙНІСТЬ ТА ЯКІСТЬ ЗЕРНА ПШЕНИЦІ М'ЯКОЇ ОЗИМОЇ
}

\section{Рецензент - доктор сільськогосподарських наук, професор П. В. Писаренко}

Наведені дані щъодо впливу попередників: чистого пару, гороху й кукурудзи на силос на врожайність та якість зерна пшениці м'якої озимої. Виявлено, щзо найбільшу врожайність $і$ найкращці показники якості зерна мала пшениця озима, вирощена після чистого пару. Найгіриим попередником за даних умов була кукурудза на силос; після гороху отримано середню врожайність та показники якості зерна пшениці озимої. Тому важливим резервом збільшення врожайності зерна пшениці та підвищуення ї̈ якості є науково обтрунтований вибір попередника.

Ключові слова: пшениця м'яка озима, попередники, урожайність, маса 1000 зерен, натура, склоподібність, вміст білку, якість клейковини.

Постановка проблеми. Нині, як і раніше, існує проблема збільшення врожайності сільськогосподарських культур із високою якістю. Значна кількість зерна пшениці озимої не відповідає вимогам, що ставляться до продовольчого зерна, що, в свою, чергу впливає на якість борошна та хліба. Для одержання великої та стабільної врожайності зерна пшениці озимої високої якості важливе значення має правильне розміщення цієї культури в сівозміні з урахуванням біологічних особливостей сорту.

Одним із важливих резервів збільшення врожайності зерна пшениці, стабілізації виробництва зерна $\epsilon$ ретельний науково обгрунтованний підхід до вибору попередників $[2,6]$.

Аналіз основних досліджень і публікацій, в яких започатковано розв'язання проблеми. Сучасні високопродуктивні сорти пшениці озимої характеризуються підвищеними вимогами до родючості грунту, вмісту вологи в ньому та його чистоти від бур'янів. У зв'язку з цим зростає роль попередників за вирощування таких сортів [7].

Пшениця озима вимоглива до попередників. Особливо зменшується іiї продуктивність за безмінного вирощування. Це призводить до збіль- шення забур'яненості посівів, особливо тими бур'янами, що пристосувалися до росту саме в посівах даної культури. Так, за даними Миронівського інституту пшениці, за безмінного вирощування пшениці озимої кількість бур'янів збільшується в 2-5 разів, причому негативний вплив забур'яненості не зменшується і від внесення добрив та гербіцидів $[1,6]$.

На всіх етапах розвитку сільського господарства сівозміна становила основу технології. Інтенсивна технологія краще реалізує потенціальні можливості попередника, ніж звичайна. 3 іншого боку, інтенсивні технології дещо зменшили роль попередника, поскільки негативні наслідки повторного розміщення культури нейтралізувалися за допомогою хімічних засобів захисту рослин від шкідливих організмів [4].

Розміщення пшениці озимої в сівозміні після кращих попередників не потребує додаткових витрат ресурсів, однак забезпечує отримання додаткової кількості зерна цієї культури [5].

Мета досліджень та методика їхнього проведення. Метою досліджень $\epsilon$ визначення впливу попередників на врожайність і якість зерна пшениці озимої.

Предмет досліджень - сорт пшениці озимої Вдала. Дослідження проводили в умовах Лівобережного Лісостепу на базі дослідного поля Полтавського інституту агропромислового виробництва імені М. І. Вавилова у виробничих умовах в межах однієї сівозміни на чорноземах звичайних середньосуглинкових.

Проводячи дослідження, ми користувалися методикою польового досліду $\quad$ Б. А. Доспєхова. Метод проведення досліджень - польовий, доповнений лабораторними аналізами. Урожайність визначали методом суцільного зважування. Показники якості зерна пшениці озимої визначали згідно 3 державними стандартами та прийнятими методиками в лабораторії якості зерна ПДАА [3].

* Керівник-доктор сільськогосподарських наук, професор Г. П. Жемела 


\section{СІЛЬСЬКЕ ГОСПОДАРСТВО. РОСЛИННИЦТВО}

Агротехніка вирощування пшениці озимої була загальноприйнятою. У процесі досліджень вивчали вплив попередників (чистий пар, горох, кукурудза на силос) на урожайність, фізичні й технологічні показники якості зерна пшениці озимої сорту Вдала.

Результати досліджень. За результатами досліджень більша урожайність спостерігалася в 2011 р., оскільки 2010 р. характеризувався несприятливими погодними умовами в зимовий період і під час достигання зерна пшениці озимої. Так, у 2010 р. урожайність сорту Вдала після попередника чистий пар, який ми взяли за контроль, становила 4,85 т/га. Урожайність даного сорту після попередника горох та кукурудза на силос була істотно меншою, порівняно 3 контролем $\left(\mathrm{HIP}_{05}=0,24 \mathrm{~T} / г \mathrm{a}\right), \mathrm{i}$, відповідно, становила 4,54 т/га та 4,06 т/га. У 2011 р. урожайність пшениці озимої після чистого пару становила 6,25 т/га. На рівні контролю спостерігається урожайність сорту після попередника гороху $\left(\mathrm{HIP}_{05}=0,26 \mathrm{t} /\right.$ га). Суттєво меншою була урожайність пшениці після кукурудзи на силос.

За роки досліджень найбільшу урожайність сорту Вдала отримано після чистого пару (табл. 1).

Одним із фізичних показників, що широко використовується в практиці характеристики зерна,
$€$ його крупність, яка виражається масою 1000 зерен. Вона залежить від цілої низки факторів, із-поміж яких важливе значення мають і попередники. У наших дослідженнях максимальна маса 1000 зерен була після попередника чистий пар і становила 42,1 г (2011 рік). Зменшення маси 1000 зерен спостерігалося в 2010 році після попередника кукурудза на силос $(35,1$ г).

За вирощування пшениці озимої як по чистому пару, так і після гороху склоподібність була практично на одному рівні. У тих випадках, коли склоподібність становить не менше $70 \%$, зерно відносять до першого, не менше $60 \%$ - другого, не менше $50 \%$ - третього і не менше $40 \%$ - четвертого класів (табл. 2).

Вміст клейковини не лише поліпшує харчову цінність хліба, а й є основною умовою добрих хлібопекарських якостей борошна, значною мірою зумовлюючи об'ємний вихід хліба, шпаристість і зовнішній вигляд.

Від кількості клейковини та іiі якості в основному залежать реологічні властивості тіста. Найбільший вміст клейковини за обидва роки мала пшениця озима після попередника чистий пар (2010 p. - 26,1\%, 2011 р. - 24,4\%), найменший - після кукурудзи на силос у 2011 р. $(22,8 \%)$.

\section{1. Урожайність пшениці озимої залежно від попередника, $\mathrm{m} / 2 \mathrm{a}$}

\begin{tabular}{|c|c|c|}
\hline Попередник & $2010 \mathrm{p}$. & $2011 \mathrm{p}$. \\
\hline Чистий пар & 4,85 & 6,25 \\
\hline Горох & 4,54 & 6,17 \\
\hline Кукурудза на силос & 4,06 & 5,65 \\
\hline HІР $_{05}$ & 0,24 & 0,26 \\
\hline
\end{tabular}

\section{2. Вплив попередників на фізичні показники якості зерна пшениці озимої}

\begin{tabular}{|c|c|c|c|c|c|c|}
\hline \multirow{2}{*}{ Попередник } & \multicolumn{2}{|c|}{ Маса 1000 зерен, г } & \multicolumn{2}{c|}{ Натура, г/л } & \multicolumn{2}{c|}{ Склоподібність, \% } \\
\cline { 2 - 6 } & $2010 \mathrm{p}$. & $2011 \mathrm{p}$. & $2010 \mathrm{p}$. & $2011 \mathrm{p}$. & $2010 \mathrm{p}$. & $2011 \mathrm{p}$. \\
\hline Чистий пар & 39,0 & 42,1 & 795 & 785 & 49 & 50 \\
\hline Горох & 36,8 & 38,1 & 780 & 770 & 48 & 47 \\
\hline $\begin{array}{c}\text { Кукурудза } \\
\text { на силос }\end{array}$ & 35,1 & 37,0 & 770 & 770 & 45 & 45 \\
\hline
\end{tabular}

\section{3. Вплив попередників на якість зерна пшениці озимої}

\begin{tabular}{|c|c|c|c|c|c|c|}
\hline \multirow{2}{*}{ Попередник } & \multicolumn{2}{|c|}{ Вміст клейковини, \% } & \multicolumn{2}{|c|}{$\begin{array}{c}\text { Якість клейковини, } \\
\text { од. ВДК-1 }\end{array}$} & \multicolumn{2}{c|}{ Вміст білка, \% } \\
\cline { 2 - 7 } & $2010 \mathrm{p}$. & $2011 \mathrm{p}$. & $2010 \mathrm{p}$. & $2011 \mathrm{p}$. & $2010 \mathrm{p}$. & $2011 \mathrm{p}$. \\
\hline Чистий пар & 26,1 & 24,4 & 95 & 98 & 12,8 & 12,0 \\
\hline Горох & 24,2 & 23,4 & 95 & 100 & 12,3 & 11,6 \\
\hline $\begin{array}{c}\text { Кукурудза } \\
\text { на силос }\end{array}$ & 23,1 & 22,8 & 95 & 95 & 11,1 & 10,7 \\
\hline
\end{tabular}


Вміст білку в зерні пшениці озимої змінювався аналогічно вмісту клейковини. Як видно $з$ даних таблиці 3 , як у 2010, так і в 2011 роках найбільший вміст білку був у зерні пшениці озимої, вирощеній після чистого пару, й становив 12,8 \% та 12,0 \% відповідно. Після гороху цей показник був дещо меншим і становив $12,3 \%$ у 2010 р. та $11,6 \%$ у 2011 році.

У цілому можна констатувати, що врожайність зерна пшениці озимої в умовах Лівобережного Лісостепу дослідного поля Полтавського інституту агропромислового виробництва імені М. І. Вавилова значно більшою була після всіх попередників у 2011 році.

\section{БІБЛІОГРАФІЯ}

1. Гриник I. В. Продуктивність пшениці озимої залежно від попередників і рівнів живлення в умовах Лісостепу // Вісник аграрної науки. 2001. - №7. - С. 14-15.

2. Демішев Л. Ф. Складові успіху при вирощуванні озимої пшениці. // Зберігання та переробка зерна. - 2004. - №3. - С. 27.

3. Жемела Г. П., Шемавньов В. І., Маренич М. М. Технологія зберігання та переробки продукції рослинництва: навч. посіб. - Дніпропетровськ, 2005. -248 c.
За показниками якості зерна спостерігається зовсім протилежне: в 2010 р. вони кращі, ніж у 2011 році (табл. 3).

\section{Висновки:}

1. Найбільша врожайність пшениці озимої була після чистого пару, менша - після кукурудзи на силос.

2. Визначено, що попередники впливають на показники якості зерна (вміст клейковини, іiі якість, вміст білку). Всі вони були значно кращими після чистого пару, дещо гіршими - після гороху. За два роки досліджень зерно найгіршої якості отримано після кукурудзи на силос.

4. Загальне землеробство / За ред. В. П. Гордієнка. - К.: Вища школа, 1988. - 302 с.

5. Кудря С. І., Клочко М. К., Кудря Н. А. Вологозабезпеченість і урожайність пшениці озимої залежно від попередника. // Вісник аграрної науки. - 2007. - №11. - С. 23-26.

6. Лихочвор В. В., Грець Р. Р. Озима пшениця. Львів: Українські технології, 2002. - 88 с.

7. Невмивако Т. В. Вплив попередників на врожайність і якість зерна пшениці озимої // Вісник аграрної науки. - 2008. - №4. - С. 74-76. 